\title{
We Need New Libraries, Not Reused Facilities
}

\author{
by Harry Tuchmayer, Column Editor
}

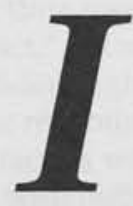

t's not that adaptive reuse is such a bad idea-in fact, under normal circumstances it's an extremely creative and socially responsible concept. The problem is, it doesn't really work for libraries. Salvaging old historic structures, such as turn-of-the century courthouses, antebellum mansions, or unique and intriguing warehouses, not only enhances a community's beauty, but also provides a real link to our past. However, to quote architect Louis Sullivan, "Form follows function," and it is my contention that in most of these instances, the form may be preserved to the detriment of the library's function.

What makes a good library? Adequate space, ease of accessibility, attractive and comfortable reading and study areas, good lighting, highly visible service points. The list goes on and on. Now, I'm no architect, but I know a good library when I see one. And an old courthouse, in a crowded downtown, with no parking and rooms with more space from floor to ceiling than from wall to wall isn't my idea of a practical and "user friendly" library.

$I$ 'm sure a good architect can take the shell of a building and create a fairly acceptable libraryin fact, I'm sitting in one as I write this editorial. But the reason that the conversion of a major department store into a main library worked for New Hanover County has as much to do with the particular characteristics of downtown Wilmington as it does with the skill and creative genius of the architect - adequate parking in an easily accessible downtown area where crime and traffic are not a problem.

For most communities, however, hand-me-down libraries are about as exciting as hand-medown clothing is for the parents of a new baby - we appreciate and might even need the clothing, but we are sadly disappointed to have to make do. In fact, most hand-me-down clothing that we do receive is generally in pristine condition, completely suitable for everyday use, and intended to supplement a newly created wardrobe. Can the same thing be said about most old structures that are offered to city or county officials as a possible library? No one gives you tattered and torn clothing soiled beyond use, or items otherwise inappropriate for your child. Is the gift of an old market, department store, or discarded office building in a deserted or decaying neighborhood any more appropriate? It's certainly not my idea of a quality hand-me-down, but it might be useful trading material next time you find yourself bartering with other departments for much needed space (or even supplies).

Although I'm sure most donors have nothing but the best interests of the community at heart, I have to wonder why they would consider leaving a perfectly salvagable building in the first place. After all, what does the new mall have that downtown or the old business district doesn't. Could it be adequate space, ease of accessibility, attractive and comfortable surroundings, high visibility ...?

I'm not advocating the abandonment of downtown, nor am I calling for more malls to be built in order to house libraries. Heaven knows we have enough malls already. But I do think it's time public officials recognize the importance of libraries. Don't get me wrong - that doesn't mean libraries have to be palatial structures, complete with gargoyles, ornate fountains, and a little art on the ceiling to boot. But they must be built with some serious thought given to how and why they are used and what makes them attractive. Remodeling an abandoned building might give us a "new" facility, but it won't necessarily give us a new library!

A failing location is still a failing location regardless of what we do. Replacing an existing business with a new library has about as much chance of succeeding as if the failing enterprise had remodeled rather than moved. Libraries are an important community investment and they should be treated as such. We need to take the time and effort to research where we will get the best return on our investment before we blindly accept just any structure. Locating libraries where people will go and use them should be our highest priority. Otherwise, we waste more money than we ever save by opting for the cheap alternative of adapting an existing structure for library use. 


\title{
Good Building Programs Make Good Libraries, New or Used
}

\author{
by Jim McKee
}

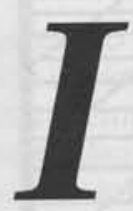

$\mathrm{t}$ would be a mistake to overgeneralize about the relative merits of "hand-me-down" renovated buildings vs. new construction in a discussion of which would make the better library. Yes, as Harry states, many an old structure has been offered to city or county officials as a possible library. Too often the idea arises with the officials themselves in an effort to save money, a venerated building, or a decaying part of town. It is even sadder that library officials occasionally succumb to such pressure and may even rationalize the decision as "the best possible", or "better than nothing."

Harry hits the nail on the head when he states that, "Libraries are an important community investment and they should be treated as such. We need to take the time and effort to research where we will get the best return on our investment before we blindly accept just any structure." True, very true! However, the "cheap alternative of adapting an existing structure for library use" may not always prove to be a bad investment or be inferior to a new building.

The key, I think, is summed up by Lester K. Smith in Planning Library Buildings. He says, "The first task is to separate the fact of library service from the building which houses it. Some people lose sight of library service from the building which houses it. Some people lose sight of the fact that the public library is a service not a structure of some kind." Many a brand, spanking, new library has lost sight of this "fact" as functionality and flexibility lost out to an architect's "vision" of what a library should be. Also, many a new library has served the community poorly by being situated on a poorly located site with little or no convenient parking.

It is the library professional's duty to inform and if necessary, evangelize the community decision makers about the library's present and future role as a community resource and investment. An underutilized library (whether new or renovated), that results from poor siting, and/or poor planning, is a truly squandered resource - and one with which the community will have to live for many years.

The real challenge is for the library planning team to undertake a service-oriented building program that is flexible enough to meet the community's need well into the future. Once the needs are determined, then the site and/or facility requirements can be dealt with. The trick is to work toward the best located, most adequately sized, and most flexibly planned library possible within existing resources. It is critical that decision makers understand that libraries are probably more akin to retail businesses than they are to other government agencies in that accessibility, parking, and an attractive facility are critical to usage. All these criteria are well-documented in library literature - but all too often one or more are ignored.

I am not necessarily advocating adaptive reuse (renovation) as an ideal solution in every case but I think it is a mistake to believe that "new" is always better. It is the library professional's job to establish the library program, but it is the architect's job to assess the merits of new construction vs. renovation. Many, if not most, old buildings offered for use as a library miserably fail to meet the criteria for selecting and planning a good library. However, every once in a while an existing facility is available in a good location, is adequately sized, and can be attractively renovated at a cost that is reasonable. Libraries do have many special requirements, such as above average floor loads, lighting, etc., and a good architect and/or engineer will be needed to assess these situations.

When renovation of an existing building is being considered as an alterative to new construction the best thing to do is assess both options with regard to your building program and recognized criteria. Most projects have a set amount of available funds which is a very large factor. The cost of new construction with related costs and, such as site acquisition, grading, paving, etc., can give you "sticker shock" and may result in an undersized facility.

In conclusion, let me say that as is true with clothes, the true test of the "hand-me-down" is in the style and the fit. There is nothing wrong with a "hand-me-down" building if it meets your library's and community's needs in a way that is clearly superior to new construction. Our state is blessed with a number of well located, adequately sized, attractive library facilities that were once grocery stores, department stores, and even telephone office buildings. Most of these buildings function extremely well and out-of-town users comment on how attractive the libraries are - and don't even know they're standing in what used to be the frozen foods section!

Stick to your building program, but keep an open mind. Every now and then you might be happier with a "hand-me-down" than a designer fashion. 


\section{Winnebago is reshaping...}

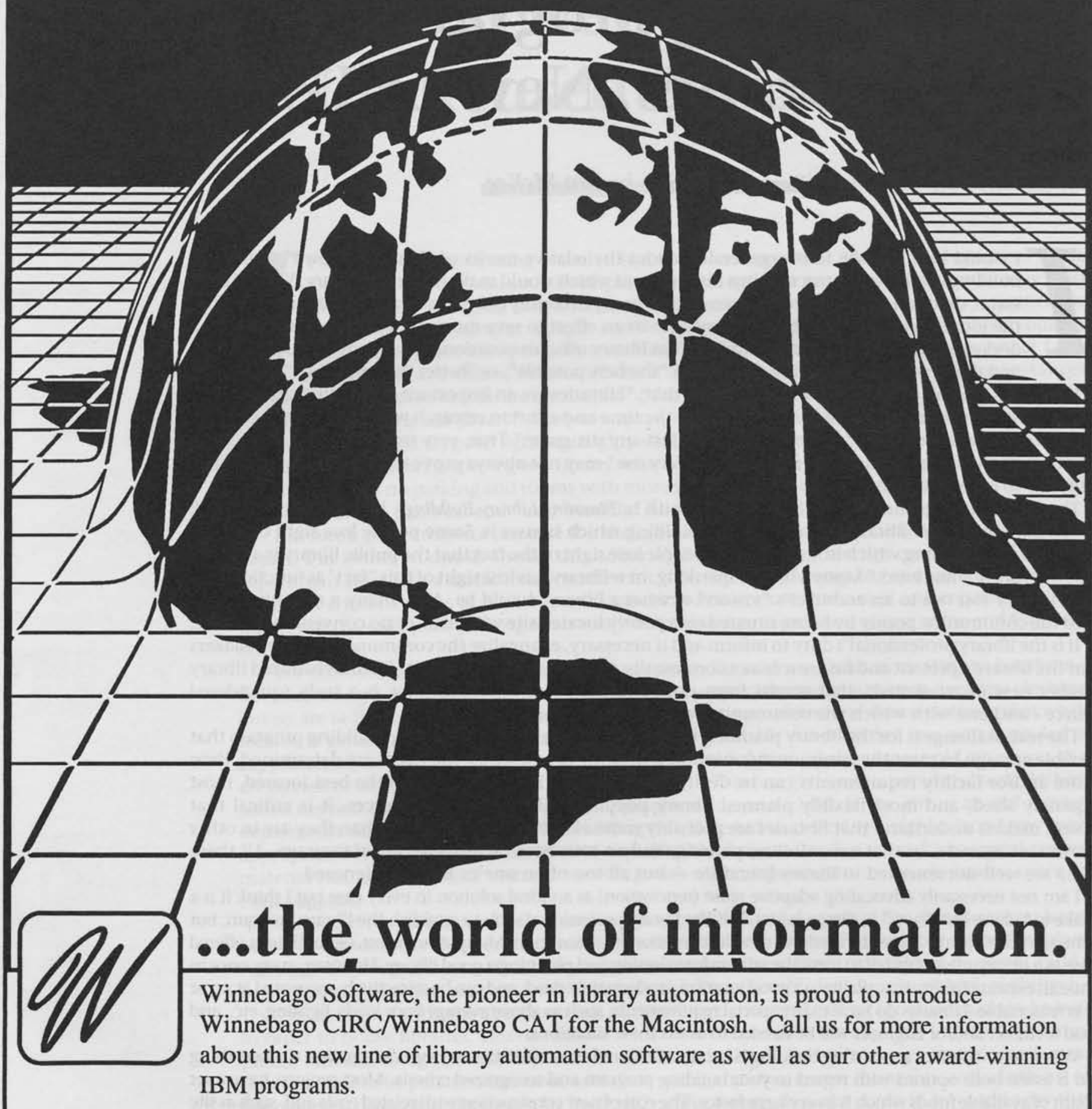

- Circulation

- Cataloging

- Card Production

- Union Catalog

- Acquisitions

- Retrospective Conversions

East Educational Services Johnny Shaver Winnebago Software Company, 1-800-533-5430, ext \# 26 